The Polish Journal of the Arts and Culture. New Series 10

(2/2019): 75-90 [ARTYKU‡]

DOI: $10.4467 / 24506249$ PJ.19.012.11984

\title{
O zmysłowych przygodach w ASMR z perspektywy posthumanizmu
}

\author{
Joanna ŁAPIŃSKA
}

\begin{abstract}
Streszczenie
W artykule autorka dyskutuje nowe zjawisko kulturowe, znane jako ASMR, w szczególności jego zainteresowanie multizmysłowością, w perspektywie posthumanistycznej, związanej z niehierarchicznością ludzkich zmysłów. Tekst analizuje wybrane filmy z gatunku ASMR opublikowane $\mathrm{w}$ serwisie internetowym YouTube, skupiając się na sposobach ukazywania w nich różnych wrażeń zmysłowych (wzrokowych, słuchowych, dotykowych, zapachowych, smakowych), stawiając tezę, że praktyki ASMR promują posthumanistyczny typ wrażliwości oraz zachęcają do wytwarzania alternatywnych trybów doświadczania świata.
\end{abstract}

Słowa kluczowe: ASMR, posthumanizm, afekty, multizmystowość, haptyczna wizualność

Joanna LAPIŃSKA, doktor nauk humanistycznych w dyscyplinie kulturoznawstwo, filmoznawczyni. Jej zainteresowania badawcze obejmują teorie i praktyki posthumanizmu, kino science fiction, przemiany współczesnej podmiotowości, nowe praktyki intymności. Publikowała, m.in., w „The Polish Journal of Aesthetics”, „Kulturze Popularnej”, „Świecie i Słowie”, „Pracach Kulturoznawczych”.

E-MAIL: joannalapinska87@gmail.com 


\section{Wstęp}

Skrót „ASMR” stosuje się na określenie zjawiska artystyczno-kulturowo-medialnego, rozwijającego się w ostatnich latach w przestrzeni internetowej, głównie na platformie YouTube, najbardziej znanego pod postacią licznych filmów wideo, publikowanych w tym serwisie przez artystów ASMR (czasami nazywających się „ASMRtists”). Filmy te prezentują przeróżne praktyki, mające na celu wywołanie specyficznego wrażenia, nazywanego w tej społeczności internetowej „mrowieniem mózgu” lub „ciarkami głowy” (ang. brain albo head tingles), skutkującego u widza odprężeniem, zrelaksowaniem, wyciszeniem, a wreszcie - zaśnięciem. ASMR jest skrótowcem pseudonaukowej nazwy „Autonomous Sensory Meridian Response”, tłumaczonej na język polski jako „samoistna odpowiedź meridianów czuciowych” (Wikipedia 2019), używanej na oznaczenie „przyjemnego uczucia mrowienia, rozpoczynającego się we wnętrzu głowy, na jej skórze i przechodzącego przez kończyny ciała, powodując ich relaksację" (Young i Blansert 2015, 4) ${ }^{1}$, pojawiającego się w odpowiedzi na różne bodźce zewnętrzne - głównie słuchowe, lecz także wzrokowe, haptyczne, smakowe, zapachowe bądź kognitywne. Ci, którzy doświadczyli tego euforycznego uczucia, opisują je jako bardzo przyjemny stan „błogiego odrętwienia”, podobny wrażeniu, że „mózg się wyłącza”, związany z „głębokim poczuciem bezpieczeństwa i komfortu” (Richard 2016).

Artysta parający się nagrywaniem filmów ASMR tworzy w nich swego rodzaju performans, podczas którego, przy pomocy różnych przedmiotów, stara się wywołać owo specyficzne, przyjemne uczucie mrowienia u widzów, mające ich zrelaksować. W tym celu stosuje najczęściej kilka z najpopularniejszych bodźców-wyzwalaczy (ang. triggers) ciarek, do których należą m.in.: powolne mówienie miękkim głosem/szeptem, rozmaite dźwięki wydawane przez wargi (np. podczas jedzenia, mówienia), odgłosy klikania, drapania, szczotkowania, biały szum, malowanie/rysowanie, bliska obecność drugiej osoby skupiającej się tylko na nas (tzw. osobista uwaga, ang. personal attention), modelowanie fryzury, zabawa włosami i inne (Sadowski, 2016, 32). W danym filmie najczęściej pojawia się kombinacja kilku spośród wymienionych bodźców mających zbawiennie oddziaływać na widzów - na przykład $\mathrm{w}$ tych imitujących wizytę u fryzjera zobaczymy połączenie bliskiej obecności drugiej osoby (tzw. bodźca osobistej uwagi) z odgłosami szczotkowania włosów, aplikowania na nie kosmetyków przy pomocy atomizera, szczęku nożyczek, stukania paznokci o przeróżne fryzjerskie przyrządy itp.

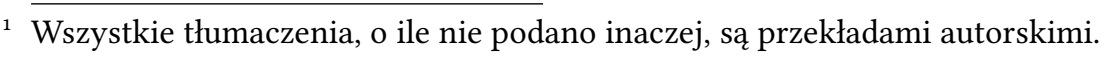


Najczęściej wyróżnia się dwie szerokie kategorie filmów ASMR, do których należą te związane z odgrywaniem ról (ang. roleplay bądź role-play videos) (Bennet 2016) oraz te, które Helga Sadowski nazwała „relaksacją powtarzalną" (ang. repetitive relaxation) (Sadowski 2016, 161). W utworach pierwszego typu artystka ${ }^{2}$ wciela się w pewną rolę (np. makijażystki, fryzjerki, lekarki, stewardessy), aby imitować wykonywanie różnych czynności z nią związanych na głowie i ciele widza, osadzonego w miejscu klienta salonu czy badanego pacjenta. Powolne ruchy wykonywane przez artystkę w kierunku kamery i mikrofonów, całkowite poświęcenie uwagi kamerze umieszczonej w miejscu, gdzie powinna znajdować się głowa widza, imitowanie nawiązywania z oglądającym serdecznej, prawie intymnej relacji to cechy charakterystyczne performansów odgrywanych w filmach z pierwszej kategorii, mających wprowadzić nas w stan całkowitego odprężenia. W utworach drugiego typu zaś artysta często pozostaje skryty poza ramą kadru, a w centrum zainteresowania znajdują się liczne akcesoria, które służą wytworzeniu interesujących, wzbudzających przyjemne ciarki efektów dźwiękowych. Uczucie odprężenia ma zostać wywołane dzięki rytmicznemu powtarzaniu pewnych czynności (głównie drapania i stukania paznokciami o przedmioty, ich zgniatania, uciskania, pocierania...), skutkujących wybrzmiewaniem interesujących, chrupiących dźwięków powodujących ciarki. Twórcy filmów tego typu najczęściej stosują bliskie plany, w których umieszczają dane gadżety - tak, aby dostarczyć widzom mocnych bodźców wizualnych, a także, poniekąd, transferować w przestrzeń internetową inne wrażenia zmysłowe, w tym zapachowe, smakowe, dotykowe.

W niniejszym artykule przyjrzymy się wybranym przykładom filmów ASMR opublikowanych na YouTube, pod kątem ukazywania w nich różnych wrażeń zmysłowych, jak również sensualnego stosunku do bytów nieludzkich, ich materialności i afektywnych możliwości. Zobaczymy, w jaki sposób twórcy ASMR budują swoje przedstawienia wokół idei możliwości transferowania wrażeń multizmysłowych z ekranu wprost do widza - jakich technik używają, jakie zmysły i materialne akcesoria stoją w centrum ich zainteresowania. Wydaje się, że praktyki ASMR prezentują pewien alternatywny tryb doświadczania świata, wpisując się tym samym w post-

${ }^{2}$ Warto tu zauważyć, że najwięcej twórców ASMR to kobiety. Oczywiście, mężczyźni także bywają artystami ASMR, lecz najczęściej odgrywają w swoich przedstawieniach role stereotypowo kobiece. Jak wymownie zauważyła jedna z najsłynniejszych twórczyń ASMR, Maria Viktorovna z kanału „Gentle Whispering ASMR”: „niewiele jest rzeczy, o których mężczyźni mogliby szeptać tak, aby nie było to dziwaczne" (Andersen 2014, 11). 
humanistyczne podejście do otaczającej nas rzeczywistości, odżegnujące się choćby od hierarchiczności bytów i tworzenia wśród nich podziałów na „lepsze” i „gorsze”, „sztuczne” i „naturalne”. Posthumanistyczna wrażliwość proponowana $\mathrm{w}$ ASMR opiera się też na takim podejściu do świata, które już nie faworyzuje zmysłu wzroku, lecz optuje za dehierarchizacją ludzkich zmysłów. Jak zobaczymy w dalszej części artykułu, ASMR promuje nastawienie do rzeczywistości, akcentujące szczególny namysł nad materialnością świata oraz badanie jej własności z pewnym pietyzmem, nieograniczone przez stricte ludzkie uprzedzenia ${ }^{3}$.

\section{Posthumanizm i afekty. Rys teoretyczny}

Zanim przejdziemy do analizy dzieł spod znaku ASMR, warto wskazać, w jaki sposób w niniejszym tekście rozumieć będziemy posthumanizm oraz związaną z nim afektywność materialnych ciał.

Bliska nam posthumanistyczna rama teoretyczna, w której osadzamy analizy, opisana została, m.in., przez Francescę Ferrando, znaną promotorkę posthumanistycznego zwrotu w badaniach naukowych, oraz przez Monikę Bakke, wskazującą na potrzebę „refleksji na temat zmieniającej się pozycji człowieka, nie tylko wobec innych form życia, ale i artefaktów oraz przyrody nieożywionej” (Bakke 2010, 357). Według Ferrando, posthumanizm jest obecnie „najbardziej otwartą i wyczuloną ramą krytyczną, z którą możemy podchodzić zarówno do zadań intelektualnych, jak i do codziennych rytuałów egzystencji” (Ferrando 2014, 171). Oznacza to choćby takie podejście badawcze, które, odżegnując się od poruszania się w ramach dyskursów klasycznie antropocentrycznych, jest wyczulone na narastający obecnie „kryzys

3 Należy w tym miejscu zaznaczyć, że nowy fenomen medialno-artystyczny, jakim jest ASMR, oczywiście nie zaistniał w próżni. W długiej historii sztuk medialnych odnaleźć możemy więcej niż jednego prekursora bądź inspiratora tego zjawiska. Możliwości wielozmysłowego odbioru dzieła sztuki, tworzenia synestetycznego przekazu artystycznego, a także ukazywania materialności dźwięku i obrazu zajmowały rozlicznych twórców na długo przez powstaniem ASMR, m.in. w takich zjawiskach artystycznych, jak: muzyka konkretna ( $m u$ sique concrète) Pierre'a Schaeffera i Pierre'a Henry, awangardowy film dadaistyczny, surrealistyczny czy abstrakcyjny (np. eksperymenty Oskara Fischingera), dokamerowy performance czy koncepcja deep listening Pauline Oliveros. Szczegółowy opis wymienionych zjawisk i ich możliwego wpływu na sztukę ASMR wykracza poza ramy niniejszego artykułu. Bez wątpienia mogą one stanowić zachętę do eksploracji kontekstu historycznego fenomenu ASMR. 
wyjątkowości człowieka” (Bakke 2010, 337), stojącego wcześniej na szczycie drabiny bytów i spoglądającego z góry na poddany mu materialny świat. Posthumanistyczne podejście do badanej rzeczywistości miałoby być odpowiedzią na ów kryzys - mogłoby promować odejście od opisywania rzeczywistości w kontekście hierarchii (bytów czy zmysłów) oraz propagować „witalizm i egalitaryzm" (Bakke 2010, 352) podmiotów ludzkich i nie-ludzkich. Równościowa filozofia otwartości, którą pragnie być posthumanizm, pozwala „wreszcie dostrzec i docenić relacje między ciałami” (Bakke 2010, 323) oraz zwrócić uwagę na to, że wszyscy, zarówno ludzie, jak i nie-ludzie, jesteśmy zbudowani z materii mającej potencjał wpływania na innych. Ciała złączone w ten sposób znajdują się bez ustanku w swoistym „płynnym splątaniu bytów" (Ferrando 2014, 171) - trudno więc wyznaczyć początek i koniec każdego z nich, jak również ustanawiać jakiekolwiek hierarchie w ich obrębie.

Należy także wspomnieć o przyświecającej nam w kontekście rozumienia afektywności ciał koncepcji Barucha Spinozy, dotyczącej zdolności oddziaływania ciał na inne ciała, czy też wzruszania ich przez nie oraz przyjmowania na siebie ich oddziaływań, a także o jej współczesnej interpretacji zaproponowanej na przykład przez identyfikujących się z tzw. zwrotem afektywnym w kulturze Melissę Gregg i Gregory'ego J. Seigwortha. Spinozjańskie wzruszenia-afekty są, według interpretacji badaczy, czepliwymi siłami spotkania (ang. forces of encounter) (Seigworth i Gregg 2010, 2) bądź migotaniami (ang. shimmers) (Seigworth i Gregg 2010, 1, 11) powstającymi na przecięciu interakcji ciał, zarówno ludzkich, jak i nie-ludzkich, nienależącymi całkowicie do żadnego z nich. Afekty zdolne do pobudzania ciał przepływają między nimi w swoistym tańcu intensywności, czy też wspomnianym wyżej „płynnym splątaniu”, zrównując byty - w posthumanistycznym duchu.

Tak rozumiane „płynne splątanie” dotyczyć może także zmysłów, które wymykają się próbom hierarchicznego, stricte racjonalistycznego segregowania. Obecnie często zauważa się ${ }^{4}$, że każdy ze zmysłów jest de facto ekstensją zmysłu dotyku, wytworem tkanki skórnej. Tego typu posthumanistyczne, egalitarne, zrównujące podejście do roli zmysłów w życiu i doświadczeniu człowieka zasadza się na zauważeniu faktu, iż wszystkie one mają niejako wspólny początek, dlatego budowanie w ich obrębie hierarchii nie jest wskazane. Jak przekonuje Pallasmaa, „wszystkie doświadczenia zmysłowe

4 Czyni to np. Juhani Pallasmaa w znanej pracy Myśląca dłoń. Egzystencjalna i ucieleśniona mądrość $w$ architekturze (2015). 
są sposobami dotykania, związanymi tym samym z taktylnością" (Pallasmaa 2015, 110). Fiński architekt apeluje o „wielozmysłowe podejście w sztuce i w architekturze" (Pallasmaa 2015, 30). Jak się przekonamy, afektywne migotania między ciałami zaobserwowane w ASMR mogą stać ponad zmysłowymi podziałami i hierarchiami; cielesne wzruszenia wywołane rozmaitymi bodźcami mają tu więc, jak zobaczymy, charakter niejako egalitarny.

\section{Szepty, szumy, stuki. O słuchaniu}

Dźwięk jest uznawany przez wielu komentatorów za kluczowy aspekt ASMR, mający największy wpływ na pojawienie się mrowienia w ciele, a także idącego za nim uczucia odprężenia. To wrażenia dźwiękowe tworzą atmosferę w danym filmie, przywołują określone skojarzenia i kreują „czepliwe” afekty przepływające z ekranu do widza. Jak zauważa Rob Gallagher, ,jeżeli filmy ASMR w ogóle są »o « czymś, dotyczą tego, w jaki sposób dźwięk (arbitralny, przypadkowy, niewyraźny lub nieokreślony) może stać się poruszający i znaczący, gdy doświadczenia estetycznej obfitości wyłaniają się ze zmysłowego strumienia” (Gallagher 2016, 9).

Użycie zmysłu słuchu odgrywa tu główną rolę. Zarówno artysta ASMR, jak i widz filmu nasłuchują z wyczuleniem każdego dźwięku - szeptu, stuku czy szumu - przy czym pojawienie się żadnego z nich nie jest przypadkowe. Superczuły mikrofon pozostaje najczęściej w centrum akcji, zbierając wytwarzane dźwięki, w tym: pukania paznokci o srebrną kosmetyczkę ze skóropodobnego materiału, pocierania o grill mikrofonu kleistej substancji (ang. slime) czy grzebienia owiniętego plastikową folią (Gentle Whispering ASMR, 2018). Interesujące efekty dźwiękowe wytwarzane na żywo przez artystkęeksperymentatorkę w jej studiu, rozlewające się afektywnie w przestrzeni wokół, zbierane przez czuły mikrofon, mają trafiać do uszu widzów - zupełnie dosłownie poruszać ich ciała i w rezultacie działać relaksująco. Słuchanie rozumiane jest tutaj jako niescentrowana na człowieku „międzymaterialna praktyka wibracyjna” (Eidsheim 2015, 3), a dźwięk - jako siła wibracji materii, również nie-ludzkiej, zdolnej wzbudzać poruszenie w odbiorcy, który, dotknięty „czepliwością” afektu, reaguje na zdarzenie mimowolnie, pozarozumowo.

Różne przedmioty materialne (szczoteczka do czyszczenia twarzy, pędzel do nakładania kremu do golenia, liście herbaty, wałki do włosów itp. ${ }^{5}$ )

5 Akcesoria użyte w filmie opublikowanym na kanale „ASMR PPOMO” ASMR DELICATE (4K 6ofps, Relaxing, Slow, Sensitive, Drowsy) (ASMR PPOMO, 2019). 
przydatne na co dzień, lecz tutaj odarte ze zdroworozsądkowego znaczenia, są istotne głównie w kontekście ich możliwości sonicznych. Artystka, schowana za ramą kadru, w bardzo bliskim planie, pochyla się z namaszczeniem nad każdym z nich z prawdziwie dziecięcym zachwytem nad materialnością świata, aby wydobyć z akcesoriów ich nieoczywiste możliwości dźwiękowe. Prezentuje tym samym sensualny zachwyt nad materialnością nie-ludzkich bytów, podważając jednocześnie prymat zmysłu wzroku w odbiorze rzeczywistości. Posthumanistyczny tryb wrażliwości uruchamia się tutaj w momencie odcięcia widza od jego nawyków związanych choćby z patrzeniem przede wszystkim zawsze na ludzki element pejzażu, a zwyczajowym pomijaniem nie-ludzkich składników traktowanych jako tło wydarzeń. Tutaj to często człowiek pozostaje w ukryciu, a przedmioty domagają się uwagi, wypełniając swymi ciałami ekran i emanując dźwięki wprawiające inne ciała w wibracje.

\section{$4 \quad$ (A/e)fekty wizualne. O patrzeniu}

Aspekt wizualny w ASMR zawsze znajdował się na drugim planie. W początkach tego zjawiska klipy wideo, publikowane przez twórców raczkujących kanałów ASMR na YouTube, cechowały się słabą jakością obrazu, a aspekt wzrokowy zdecydowanie ustępował audialnemu, stąd też przez długi czas uznawano go za najsłabszy element filmów. Patrzenie na artystę przypominało wówczas podglądanie go w jego domowym zaciszu i zachęcało do wpisania ASMR w szersze zjawisko internetowego vlogowania (Andersen 2014, 7). Zdarzały się też filmy kręcone przez artystów w całkowitej ciemności tak, aby odciąć widza od wszelkich bodźców wzrokowych. Jednakże, wraz z rozwojem zjawiska w ostatnim czasie i postępującą profesjonalizacją twórczości artystów oraz adaptowaniem najnowszych rozwiązań technologicznych, w tym instalowaniem mikrofonów i kamer umożliwiających nagrywanie dźwięku i obrazu wysokiej jakości - mamy do czynienia z przekroczeniem wspomnianego aspektu vlogowania, związanego głównie z podglądaniem bohatera/twórcy filmu podczas wykonywania codziennych czynności ${ }^{6}$,

6 Aspekt ASMR, o którym mowa, a który możemy nazwać voyerystycznym, został już rozpoznany przez badaczy, np. przez Helgę Sadowski. Autorki filmów ASMR wpisywać by się miały w nurt tzw. internetowych „cam girls”. Jak podkreśla badaczka, opis vlogujących autorek filmów ASMR w tego typu prostych kategoriach fetyszystyczno-voyerystycznych nie jest jednak wystarczający - stanowi tylko aspekt tego zjawiska (Sadowski 2016, 166 i 184). 
a także z dowartościowaniem innych, pozadźwiękowych bodźców, mogących wywołać uczucie mrowienia.

Najczęściej w ASMR oglądamy połączenie wielu bodźców mających działać na nas wielokanałowo. W jednym ze swoich filmów autorka kanału „Gentle Whispering ASMR” (Gentle Whispering ASMR, 2018) bawi się purpurowym żyrandolem zbudowanym z metalicznie połyskujących okręgów zawieszonych na metalowym stelażu. Oglądamy tu feerię lustrzanych migotań, które przeplatają się z uderzeniami kółek o mikrofon ukryty w środku konstrukcji, tworząc istny koktajl wrażeń zmysłowych. Film to przykład tzw. wizualnego ASMR, do którego należy też wideo innej performerki (Caroline ASMR 2017), w którym ta najpierw bawi się ukazanym w bardzo bliskim planie różowym i niebieskim piaskiem kinetycznym - przesypuje go z miejsca na miejsce, uklepuje, rozgniata, tnie nożem - a następnie setkami umieszczonych w kilku szklanych wazach z wodą żelowych, barwnych, migoczących kuleczek, które miesza dłońmi i przesypuje między palcami.

Wizualność w ASMR często wiąże się też z patrzeniem na pokawałkowane ciało - w kadrze znajdują się zazwyczaj tylko dłonie, palce bądź fragmenty twarzy artysty. To posthumanistyczne ciało zdolne do afektywności - fragmentaryczne, płynne, z nieostrymi granicami. Pod tym względem ciekawy jest też status ciała widza, które często bywa unieruchomione oraz zależne od drugiej osoby - zwłaszcza w filmach typu roleplay, w których widz traktowany jest jak pasywny obiekt, względem którego artysta wykonuje dane aktywności, co powodować ma uczucie ulgi połączonej z przyjemnością (Bennet 2016). Często granice ciała widza nie są wyraźnie określone umownie jego głowa ma znajdować się w miejscu kamery, a uszy w miejscu mikrofonów, lecz, oczywiście, nie jest to regułą. We wspomnianym filmie artystka bawiąca się żyrandolem umieszcza w jego wnętrzu mikrofon, co ma wywołać efekt zanurzenia widza we wnętrzu konstrukcji - lecz jednocześnie wciąż zwraca się do kamery, szepcze i patrzy mi w oczy, prowokując do namysłu nad granicami mojego ciała (Gentle Whispering ASMR, 2018). Pytam więc: czy moja głowa znajduje się we wnętrzu żyrandola, a moje uszy ocierają się o jego metaliczne krążki? Czy też jestem zewnętrznym obserwatorem tego procesu? 


\section{Puszyste mikrofony i masaż kamery. O dotykaniu}

Taktylność w ASMR przyjmuje różne oblicza. Laura Marks w znanej koncepcji haptycznej wizualności zaproponowała definicję obrazów dotykowych/ haptycznych (ang. haptic images), które zachęcać mają do „wielosensorycznej, intymnej i ucieleśnionej percepcji, nawet gdy postrzegania, do których się odwołują, są wyłącznie widzeniem i słyszeniem” (Marks 2002, 133). Filmy ASMR ochoczo eksperymentują w zakresie tworzenia tego typu obrazów audiowizualnych - zwanych przez Marks haptycznymi - które mają „zachęcać do [wytwarzania] cielesnej relacji między widzem a obrazem" (Marks 2002, 3) i transferować z ekranu wrażenia dosięgające widza, poruszające jego ciało.

Bez wszędobylskich i ciekawskich dłoni eksplorujących materialność otaczającej rzeczywistości świat ASMR nie miałby racji bytu. To dotyk artysty jest pierwszym elementem wprawiającym afektywną maszynę w ruch. Pocierając czy głaszcząc przeróżne przedmioty, badając ich fakturę i ciężar, performer w danym przedstawieniu, za pomocą dotyku, steruje wydobyciem z nich efektów dźwiękowych i wizualnych. Nie poprzestaje, oczywiście, na dotykaniu rekwizytów, lecz - w ogromnej liczbie filmów używających bodźca osobistej uwagi - imituje dotykanie widza. Głaszcze oko kamery pędzelkiem do makijażu, wykonując delikatne, koliste ruchy przypominające malowanie bądź czyszczenie, a następnie symuluje dotykanie twarzy - najpierw stuka w nią pojedynczym palcem, potem kilkoma, płynnie przechodząc do hipnotyzujących, masujących ruchów całymi dłońmi (Gibi ASMR 2016). Inna artystka wykonuje tzw. „masaż głęboki mózgu i skóry głowy” (ASMRMagic 2018), drapiąc i głaszcząc (palcami i licznymi przedmiotami, w tym silikonowymi gąbkami do zmywania, wachlarzem z piór, pędzlem do makijażu, lateksowymi rękawicami) puszyste, miękkie nakładki umieszczone na mikrofonach ustawionych po obu stronach ekranu, w miejscach przeznaczonych dla uszu widza. Nie odzywa się ani słowem, nie pokazuje też twarzy, pozostając na drugim, nieostrym planie, skąpana w bladoróżowej niby-mgle.

Iście synestetyczne pomieszanie wrażeń zmysłowych, gdy masaż dłońmi jest transponowany na puszyste brzmienia dźwiękowe, leży w centrum wizualnej haptyczności ASMR. Jak myślę, rezonuje tu też idea posthumanistycznej wrażliwości z jej wielosensorycznością postrzegania świata, ignorująca prymat zmysłu wzroku, odżegnująca się od używania ludzkiej mowy i słów do opisu rzeczywistości. 


\section{Czy mogę cię obwąchać? O zapachach}

Węch był od zawsze prawdopodobnie najbardziej niedocenianym zmysłem we współczesnym świecie zachodnim (Classen, Howes i Synnott. 1994, 3). Jednakże od pewnego czasu to się zmienia - co udaje się zaobserwować także w interesującym nas zjawisku. Mimo iż nie może on, z oczywistych powodów, zostać bezpośrednio zaangażowany podczas oglądania materiałów audiowizualnych, nie jest pomijany przez artystów ASMR. Wręcz przeciwnie - odnajdują oni coraz to nowe sposoby, aby wpisać sferę zapachową oraz czynność wąchania w uniwersum zjawiska mrowienia mózgu. W przestrzeni internetowej znajdziemy filmiki, w których performerzy poszukują coraz ciekawszych i niebanalnych sposobów na przełożenie wrażeń związanych z węchem na efekty dźwiękowe i wizualne, afektywnie docierające do widza pod postacią ciarek. Dla przykładu: mogą oni wcielać się w role obwąchującego nas psa (Seafoam Kitten's ASMR 2018) bądź... jeża (aplikując tzw. bodziec niuchania, ang. sniffing trigger) (DreamMaker ASMR 2017), sprzedawcę perfum (ASMRrequests 2017), zielarza czy alchemika przygotowującego pachnący eliksir miłości (Psychedelic Journeys by Reality 2017). Bodźce zapachowe idą tu w parze $\mathrm{z}$ innymi - dźwiękowymi, wizualnymi, dotykowymi.

Laura Marks proponuje kilka sposobów, w jaki media audiowizualne mogłyby ukazywać zapach. Pierwszym z nich jest przedstawienie na ekranie samej czynności wąchania - tak, że możemy łatwo zidentyfikować się z bohaterem odczuwającym w danym momencie jakiś, przyjemny bądź nie, zapach. Drugim - dodajmy, obficie eksploatowanym przez ASMR - jest użycie dźwięku w powiązaniu z bliskim planem, gdyż ten „pozwala nam zbliżyć się do obrazu, zbliżyć do tego stopnia, że poczujemy zapach” (Marks 2017). Ostatnim zaś byłoby użycie wspomnianego już obrazu dotykowego/haptycznego - często niewyraźnego, ziarnistego, stawiającego „opór kontroli sprawowanej nad wzrokiem" (Marks 2017) - który zachęca do zbadania go w sposób multizmysłowy.

Artyści ASMR wąchają na ekranie różne pachnące przedmioty - perfumy w szklanych butelkach lub aplikowane bezpośrednio na blottery, świece, fiolki z olejkami eterycznymi, słoiki z ziarnami kawy - oraz, oczywiście, podsuwają je niejako „pod nos” widzowi, zbliżając je w stronę kamery-głowy. Jednocześnie stukają paznokciami w powierzchnie wąchanych przedmiotów, raz po raz uderzają szklanymi fiolkami o siebie, potrząsają butelkami z płynami bądź szepczą nam do ucha, próbując za pomocą efektów dźwiękowych 
i wizualnych wzbudzić w ciele mrowienie. Nierzadko w kadrze widać także unoszący się dym, np. z zapalonych kadzideł, wpisujący się w wizualny protokół dotyczący ukazywania zapachu na szklanym ekranie.

Haptyczność obrazów związanych z zapachem, zapraszających do przekraczania stricte ludzkich nawyków ich oglądania, jest także na porządku dziennym w ASMR. Znajdziemy tu zbliżenia poszczególnych czynności związanych z przygotowywaniem potraw, np. rozdrabniania i ucierania aromatycznych produktów spożywczych (ziół, orzechów, ziaren kawy, rozmaitych przypraw) w moździerzu (Mixed ASMR 2016), a także przepisy na kompletne dania prezentowane w stylistyce ASMR $^{7}$ - przy czym czynnik ludzki jest tu tylko katalizatorem pewnych procesów, nie stoi zaś w centrum wydarzeń. Kucharz pozostaje anonimowy - prawie nigdy nie widzimy jego twarzy a materialność obiektów nie-ludzkich domaga się wzmożonej uwagi i zaprasza do multisensorycznej eksploracji obrazu.

\section{Chrupanie pikli i picie perfum. O smaku}

Jedzenie przeróżnych potraw i dźwięki z tym związane są bodaj jednym z najczęściej wykorzystywanych bodźców w ASMR. Filmy dokumentujące czynności spożywania, najczęściej z towarzyszeniem wzmocnionych dźwięków chrupania, rozgryzania, przełykania, doczekały się nawet swojej własnej roboczej nazwy gatunkowej ${ }^{8}$. Te dość kontrowersyjne utwory mieszczą się w swoistej strefie „pomiędzy” - przez jednych włączane do królestwa ASMR, przez innych, najczęściej mizofoników, odrzucane jako odstręczające.

W kwestii jedzenia na ekranie artystów ogranicza tylko ich wyobraźnia. Do nadzwyczaj dźwięcznych rzeczy chętnie spożywanych w filmikach ASMR należą ogórki kiszone, corn dogi, pieczony kurczak, sushi, ostrygi, ciastka w czekoladzie i inne chrupiące słodkości. Tutaj, podobnie jak w utworach ASMR koncentrujących się na przygotowywaniu potraw, osoba wykonująca daną czynność często jest skryta za ramą kadru, a w centrum pola widzenia, niczym święte artefakty, leżą (oraz sukcesywnie znikają) produkty do schrupania. Elspeth Probyn zauważa, że kulturowe praktyki przygotowywania i spożywania posiłków cechują się współcześnie niezwykłą zmysłowością, a nierzadko również bywają naznaczone seksualnością

7 Przepis na ciasteczka brownies znajdziemy w ASMR Baking: Extremely Fudgy Brownies (Tasty 2019)

8 To tzw. filmy mukbang. 
(Probyn 2000, 61). Ukazane w ASMR czynności nie są tu wyjątkiem. Artyści z ogromnym pietyzmem podchodzą do spożywania wybranych przez siebie dań - filmy dokumentujące tę celebrowaną czynność nierzadko trwają ponad trzy i więcej godzin. Spożywanie jest tu źródłem radości - artyści uśmiechają się do widzów, kosztując przygotowane rarytasy, próbując tym samym przekazać pozytywne uczucia towarzyszące danej czynności.

Smakowanie w ASMR nie ogranicza się jednak tylko do jedzenia potraw. Seksualne konotacje może wzbudzać bodziec typu ,jedzenie ucha” (ang. ear eating) stosowany w ogromnej liczbie filmów. Artysta używa tutaj uformowanych na kształt ludzkich uszu silikonowych nakładek na mikrofony, które poddaje przeróżnym intymnym zabiegom - lizania, podgryzania, całowania, masowania (Ting Tingles ASMR 2018). Inne interesujące przykłady związane $\mathrm{z}$ jedzeniem to spożywanie przedmiotów, które na pierwszy rzut oka nie nadają się do tego celu - na przykład banknotów, kosmetyków do makijażu czy szczoteczek do zębów (oczywiście, wykonanych z jadalnych półproduktów) ${ }^{9}$, albo picie niby-perfum (asmr choa 2019b). W ASMR nie brakuje też zwierząt występujących w rolach konsumentów chrupiących przysmaków należy do nich choćby suczka Maya, obwąchująca i smakująca kawałki warzyw i owoców podsuwanych jej przez właścicielkę (Mayapolarbear 2018).

Jak twierdzi Probyn, zwracanie uwagi na zmysłowość jedzenia może pozwolić nam myśleć bardziej etycznie o innych formach życia (Probyn 2000, 60). Podobnie jak w przypadku haptycznych obrazów zapachowych, przygody ze smakiem w ASMR opierają się na próbach przełamania antropocentrycznej perspektywy - choćby stawianiu elementów nie-ludzkich na pierwszym planie oraz swoistym, nomen omen, wgryzaniu się w materialność otaczających nas rzeczywistych przedmiotów, aby poczuć ich prawdziwość, cielesność, fakturę. Tego typu wrażliwość, nazwana przez nas posthumanistyczną, objawia się w zwrocie ku materialności podmiotu nie-ludzkiego, zdolnego do afektywnego wpływania na nas.

\section{Zakończenie}

Zdaję sobie sprawę, że zasygnalizowane motywy pojawiające się w ASMR oraz zaproponowana optyka badawcza nie wyczerpują w żadnym razie bogactwa sensów tkwiących w tym zjawisku oraz możliwości stosowania

9 Specjalizuje się w tym autorka kanału ,asmr choa” (asmr choa 2019a) 
perspektyw, z których można na nie spoglądać. Celem tekstu było przede wszystkim zwrócenie uwagi na nowe, niedostatecznie poznane, a fascynujące zjawisko kulturowe, korelujące, w moim przekonaniu, z pewnymi naczelnymi wątkami filozofii posthumanistycznej. W analizach skupiłam się na zmysłowych doznaniach prezentowanych w wybranych filmach ASMR, podkreślając niehierarchiczność zmysłów i wzajemne oświetlanie się rozmaitych wrażeń w sensualnych asamblażach kreowanych przez artystów w ich dziełach. Pragnęłam także zasygnalizować aspekt afektywny wpisany w te praktyki kulturowe - zwrócić uwagę na ukazywane w ASMR afektywne możliwości tkwiące w materialności ciał ludzkich i nie-ludzkich, dowodem których miałoby być choćby odczuwane przez widza w danej sytuacji mrowienie mózgu. Fenomen ASMR rezonuje z posthumanistycznym oglądem rzeczywistości, w którym arbitralne podziały na „ludzkie” i „nie-ludzkie”, „sztuczne” i „prawdziwe” wyraźnie chwieją się w posadach - co staje się źródłem nie odwiecznej zgrozy, lecz, o dziwo, znacznej przyjemności.

\section{Bibliografia}

Andersen, Joceline. 2014. „Now You've Got the Shiveries: Affect, Intimacy, and the ASMR Whisper Community". Television \& New Media 11: $1-18$.

asmr choa. 2019a. „EDIBLE MONEY ASMR EDIBLE BITCOIN ASMR CHOCOLATE EATING ASMR WAFER PAPER ASMR”. Dostęp: 26.12.2019. http://youtu.be/6KsjZlmqdIs.

2019b. „EDIBLE PERFUME ASMR DRINKING JUICE GULPING ASMR SPRAY ASMR COSMETIC ASMR CHANEL PERFUME PRANK Q7). Dostęp: 26.12.2019. http://youtu.be/o4q7MW7st9A.

ASMR PPOMO. 2019. „ASMR D E L I C A T E (4K 6ofps, Relaxing, Slow, Sensitive, Drowsy)”. Dostęp: 26.12.2019. http://youtu.be/-D3iCIqXo68.

ASMRMagic. 2018. „ASMR Deep Brain \& Scalp Massage (NO TALKING) Fluffy Ear to Ear Mic Brushing, Scratching, Stroking”. Dostęp: 26.12.2019. http://youtu.be/yVW4 4 PLXojWU.

ASMRrequests. 2017. „ASMR Cologne \& Perfume Shop Roleplay [Personal Attention | Soft Spoken | Whispered]”. Dostęp: 26.12.2019. http:// youtu.be/5 $\mathrm{bF}_{2 \mathrm{aU}} \mathrm{EuHI}$.

Bakke, Monika. 2010. „Posthumanizm: człowiek w świecie większym niż ludzki”. W Człowiek wobec natury - humanizm wobec nauk przyrodniczych, red. Jacek Sokolski, 337-357, Warszawa: Neriton. 
Bennett, Emma. 2016. „Relief from a Certain Kind of Personhood in ASMR Role-Play Videos". [w:] The Restless Compendium. Interdisciplinary Investigations of Rest and Its Opposites, red. Felicity Callard, Kimberley Staines i James Wilkes, 129-136. Cham: Palgrave Macmillan.

Caroline ASMR. 2017. „ASMR Satisfying Visual Triggers With Layered Sounds (incl. MOUTH SOUNDS + BREATHING) \”. Dostęp: 26.12.2019. http://youtu.be/EBUwz2msrvo.

Classen Constance, David Howes i Anthony Synnott. 1994. Aroma. The Cultural History of Smell. London and New York: Routledge.

DreamMaker ASMR. 2017. „Hedgehog ASMR Triggers: Sniffing Sounds, Mouth Sounds, Ears Blowing”. Dostęp: 26.12.2019. http://youtu.be/ tufVpidHeus.

Eidsheim, Nina Sun. 2015. Sensing Sound: Singing and Listening as Vibrational Practice. Durham and London: Duke University Press.

Ferrando, Francesca. 2014. „Posthumanism”. Kilden fournal of Gender Research, 2: 168-172.

Gallagher, Rob. 2016. „Eliciting Euphoria Online: The Aesthetics of "ASMR” Video Culture". Special Guest-Edited Issue: The Aesthetics of Online Videos 2 (40): 1-15.

Gentle Whispering ASMR. 2018. „Top Triggers 解 ASMR”. Dostęp: 26.12.2019. http://youtu.be/X2VXEiQHgIk.

Gibi ASMR. 2016. „ASMR - Face Brushing, Drawing, and Touching for Sleep (Personal)". Dostęp: 26.12.2019. http://youtu.be/X1RK2Uqfoew.

Marks, Laura U. 2002. Touch. Sensuous Theory and Multisensory Media. Minneapolis and London: University of Minnesota Press.

2017. „Logika zapachu”. Tłum. Maciej Topolski. Opcje 1.1 29-30. Dostęp: 26.12.2019. http://opcje.net.pl/laura-marks-logika-zapachu. Mayapolarbear. 2018. „ASMR Dog Reviewing Different Types of Food \#1 I MAYASMR”. Dostęp: 26.12.2019. http://youtu.be/GwkEt_IWZYQ.

Mixed ASMR. 2016. „ASMR | Making Coffee from Start to Finish”. Dostęp: 26.12.2019. http://youtu.be/DY9L_j4EZSo.

Pallasmaa, Juhani. 2015. Myśląca dłoń. Egzystencjalna i ucieleśniona madrość $w$ architekturze. Tłum. Michał Choptiany. Kraków: Instytut Architektury.

Probyn, Elspeth. 20oo. Carnal Appetites. FoodSexIdentities. London and New York: Routledge.

Psychedelic Journeys by Reality. 2017. „Love Alchemist Soft Glass Tapping, Ear Cleaning | ASMR Relaxation”. Dostęp: 26.12.2019. http:// youtu.be/UbShENaJwGk. 
Richard, Craig. 2016. „How Similar Are ASMR Tingles and Music Chills?”. ASMR UNIVERSITY. The Art \& Science of Autonomous Sensory Meridian Response. Dostęp: 26.12.2019. http://asmruniversity.com/2016/05/05/ asmr-music-chills-frisson.

Sadowski, Helga. 2016. Digital Intimacies. Doing Digital Media Differently. Praca doktorska, Linköping Studies in Arts and Science, Faculty of Arts and Sciences.

Seafoam Kitten's ASMR. 2018. „ASMR - DOG ROLEPLAY Doggo Sniffs \& Licks Your Ears! ”. Dostęp: 26.12.2019. http://youtu.be/JvCvgsSQNo.

Seigworth, Gregory J. i Melissa Gregg. 2010. „An Inventory of Shimmers”. [w:] The Affect Theory Reader, red. Melissa Gregg i Gregory J. Seigworth 1-25. Durham and London: Duke University Press.

Tasty. 2019. „ASMR Baking: Extremely Fudgy Brownies • Tasty”. Dostęp: 26.12.2019. http://youtu.be/UJqKt1llI3g.

Ting Tingles ASMR. 2018. „ASMR Ear Eating and Intense Mouth Sounds (No Talking)". Dostęp: 26.12.2019. http://youtu.be/R214C1 ${ }_{5} K X A$.

Wikipedia. 2019. „ASMR”. Wikipedia, wolna encyklopedia. Dostep: 26.12.2019. https://pl.wikipedia.org/wiki/ASMR.

Young Julie i Ilse Blansert. 2015. ASMR (Idiot's Guides). New York: Alpha Books. 


\title{
Abstract, keywords, about the author
}

\begin{abstract}
About Sensory Adventures in ASMR from the Perspective of Posthumanism

In the article, the author discusses a new cultural phenomenon known as ASMR, in particular its interest in multi-sensuality, in a posthuman perspective related to the non-hierarchical nature of human senses. The text analyzes selected ASMR videos published on the YouTube website, focusing on ways to show different sensory impressions (connected with images, sounds, haptics, aromas, flavours), putting forward the thesis that ASMR practices promote posthuman type of sensitivity and encourage the production of alternative modes of experiencing the world.
\end{abstract}

Keywords: ASMR, posthumanism, affects, multi-sensuality, haptic visuality

Joanna LAPIŃsKa holds an MA in film studies and a $\mathrm{PhD}$ in the field of humanities with the specialization in cultural studies. Her research interests include theories and practices of posthumanism, science fiction cinema, changes in contemporary subjectivity, and new intimacy practices. She published, among others, in "The Polish Journal of Aesthetics", "Kultura Popularna", "Świat i Słowo", and "Prace Kulturoznawcze".

E-MAIL: joannalapinska87@gmail.com 